\title{
MOVEMENT POPULATION IN THE SECOND OF XX AND BEGINNING OF XXI CENTURY: THE CASE NORTHEASTERN MONTENEGRO
}

\author{
Goran Rajović, Jelisavka Bulatović, Researchers \\ College of Textile Design, Technology and Management, Belgrade, Serbia \\ E-mail: dkgoran.rajovic@gmail.com, jelisavka.bulatovic@gmail.com \\ Phone: 0038161/19-24-850, 003861/3082651
}

\begin{abstract}
This paper analyzes population trends northeast of Montenegro in the second half of the twentieth and early twenty-first century. The population has increased in the period 19482003 to $2.16 \%$, but with a tendency to decline from 1981 . The population in are period 19812003 , decreased by 14,674 , or $21.16 \%$. Parameters of natural population indicate a negative trend. So the natural increase in 2003 in the municipality was Andrijevica - $4.6 \%$ o, in the municipality of Plav $4.21 \%$, and Berane $9.29 \%$, significantly lower than in the beginning of the seventies. Population migration indicates uneven density and population concentration. The existence of a large number of settlements up to 500 populations (81) is not suitable for modern flow to vital economic development of the region.
\end{abstract}

\section{KEYWORDS}

Northeastern Montenegro; Density of population; Natural change; Migration.

Northeastern Montenegro covers an area of $1486 \mathrm{~km}^{2}$ and the population census in 2003 there lived 54658 inhabitants, or $36.8 \mathrm{in} / \mathrm{km}^{2}$. It covers three municipalities: Berane, Andrijevica and Plav. The paper provides a review and interpretation of the basic parameters of population trends northeastern of Montenegro in the second half of the twentieth and early twenty-first century.

Unlike the nineties of the last century, the population of the region during the seventies, moving out to a much lesser extent, we can explain the material well-being of the former Yugoslavia. Specifically, the seventies of the last century, many remained in my memory as a period when the well-earned and well-lived. In this regard, we should not be surprised that in most walks of socialism remained in my memory as the past is better than the present meager (Bolčić and Milić, 2002). But in the early eighties of the last century, Yugoslav economy began to show signs of crisis. In this regard, the fall in the population of northeastern region of Montenegro, at that time, it seems to us quite expected. In fact, many companies have started to noticeably reduce the workforce, and the process of job creation has slowed. It is also a time of mass migration of population from rural to urban areas, or temporary work abroad.

Nineties of the last century, represent an extremely complex period in the social life of our population. In addition to long-term demographic factors on the development of the region seemed a series of major historical events. "The disintegration of the former Yugoslavia, the war in the region, the sanctions of the international community, the social and political changes, the deep economic crisis, military intervention, political developments, institutional crisis... Feeling, above all, economic and existential uncertainty, the basic characteristics of people's lives during this period that the individual and psychological NEW" (Tucović and Stevanović, 2007). The account should be taken of the consequences of transition in 2000, the most important being the increase of unemployment, poverty, increased mortality rates, shorter life expectancy.

Migration of the population is characterized by uneven settlement density and population concentration. The classification of settlements in northeastern Montenegro by population size in 2003, show that in the region of the village had as many as 18 to 100 people, or 81 to 500 village residents. These settlements are characterized by demographic exhaustion of resources, due to the negative net migration, and because of the lack of biological population replacement, as well as age and education structure of the population. While the population of the village a little off, on the other hand there is a strong concentration of population in Berane, Luge Beranske, Gusinje and Plav, which results in 
demographic imbalance and large differences in population density and population between spatial entities, with particular demographic, economic and social polarization.

\section{RESEARCH METHODOLOGY}

This paper has several objectives. First of all, the analysis of the existing literature aims to establish the number and density of the population of northeastern Montenegro. The next goal is to show the change in population in the region. And finally, we need to identify the reasons and motives of population movements and highlight the factors that have led to the migration of the population.

The methodology is primarily based on an analysis of the existing literature on the population of the region and statistics. From the existing literature, we used both domestic and those published in the international literature. On this occasion of the international publication emphasize this: Holmes (1971), Foord (1975), Parr (1987), Zah (1994), van der Laan (1998), Artis and Romani \& Surinach (2000). There are literature monographs on population, proceedings and textbooks. Were studied and written sources on the internet. The scientific explanation of terms, we applied two methods are used: analytic and synthetic. Analytical methods are considered some of the dimensions of the research topic, and a synthetic whole, the interconnections between the case and suggested measures that derive there from.

\section{RESULTS AND DISCUSSION}

Number and population density. The population of Northeastern Montenegro is characterized by steadily declining in relation to the dynamics of the population. This in 1948 the population of the region seemed $14.17 \%$ of the population and $8.12 \%$ in 2003 .

The percentage increase of population, accounted for 1948-2003, 43.96\%. However, northeastern Montenegro shows significant deviations from these population dynamics. Thus, the percentage increase in population during the period amounted to 1948-2003, $2.16 \%$, but with a tendency to decline from 1981. Namely, in the period 1981-1991 population of Northeastern Montenegro is reduced from - 0,63\% to - $6.31 \%$, from 1991 $2003-6.31 \%$ to $-15.9 \%$. The general conclusion is that the Northeastern Montenegro, had over a period of extreme depopulation of 1981, which had a negative impact on the overall social and economic developments, and that means the population decline in the near past thirty years. The population in northeastern Montenegro, in are period 1981-2003 decreased by 14,674 , or $21,16 \%$.

Table 1. Change of population in Montenegro and the region in the period 1948-2003

\begin{tabular}{|c|c|c|c|c|c|c|c|}
\hline- & 1948. & 1953. & 1961. & 1971. & 1981. & 1991. & 2003. \\
\hline \multicolumn{8}{|c|}{ POPULATION } \\
\hline Montenegro & 377.189 & 419.873 & 471.896 & 529.604 & 584.310 & 615.037 & 673.094 \\
\hline Region & 53.477 & 57.973 & 62.993 & 68.893 & 69.332 & 64.954 & 54.658 \\
\hline \multicolumn{8}{|c|}{ The percentage share of the population of Montenegro } \\
\hline Region & 14,18 & 13,81 & 13,35 & 13,01 & 11,87 & 10,56 & 8,12 \\
\hline \multicolumn{8}{|c|}{ The percentage increase or decrease in population } \\
\hline- & $1948 / 53$ & 1953/61. & $1961 / 71$. & $1971 / 81$. & $1981 / 91$. & 1991/2003. & $2003 / 48$. \\
\hline \multirow{2}{*}{ Montenegro } & 42.684 & 52.023 & 57.708 & 54.706 & 30.727 & 58.060 & 295.905 \\
\hline & $11,32 \%$ & $12,40 \%$ & $12,23 \%$ & $10,33 \%$ & $5,26 \%$ & $9,44 \%$ & $43,96 \%$ \\
\hline Region & $\begin{array}{r}4.496 \\
8,41 \% \\
\end{array}$ & $\begin{array}{l}5.020 \\
8,66 \%\end{array}$ & $\begin{array}{l}5.900 \\
9,37 \%\end{array}$ & $\begin{array}{c}-439 \\
-0,63 \%\end{array}$ & $\begin{array}{l}-4.378 \\
-6,31 \%\end{array}$ & $\begin{array}{c}-10.296 \\
-15,9\end{array}$ & $\begin{array}{c}1.181 \\
2,16 \%\end{array}$ \\
\hline
\end{tabular}

Source: Statistical Office of Montenegro, Census of Population (appropriate year), calculations by.

Under the influence of general demographic principles, but also many geographical, historical, socio-economic factors in northeastern Montenegro demographics present significant spatial differences. "Urbanization and industrialization, and geographic environment and unfavorable, as the dominant factors of population transfer, led to the 
emergence of the concentration of people in a favorable area, and the depopulation of the neighboring mountain of unfavorable areas, or to discharge them from the population and their" drip "in one of the first, the more favorable areas "(Jaćimović, 1989).

Based on the demonstrated tendency of the forward movement of the total population in northeastern Montenegro, it is possible to single out one hand and on the other depopulated areas of population concentration areas (see map no. 1). The depopulation of areas which include 85 from a total of 113 villages, or $72.81 \%\left(1082 \mathrm{~km}^{2}\right)$, the total area of the region $\left(1.1486 \mathrm{~km}^{2}\right)$, census 1971 lived 37851 inhabitants (59.94\% of total population), and in 2003.year 9578 population (17.52\% of total population). Therefore, depopulation is evident in the demographic sphere in ...... its lack of natural regeneration, changes in distribution and density.... (Spasovska and llić, 1989). For example, pronounced depopulation in rural areas, and who could not keep the population was (an index for the period 1971-2003, settlements Kurikuće 28.8, Dulipolje 29.0; Seoca 30.0, Bastahe 38.5; Kralje 40.3, Upper Ržanica 45.2...). Areas of population concentration in growth of population, 1971 census they were living in 31042 people (45.06\% of total population), and 45080 inhabitants in 2003 (82.47\% of total population). A substantial population growth in that period, record the settlement in the vicinity of Berane: Dolac (index 212.5), Pešca (index 197.9), Luge (index 150.6), Beran Selo (index 162.9), Lužac (index 107, 5).

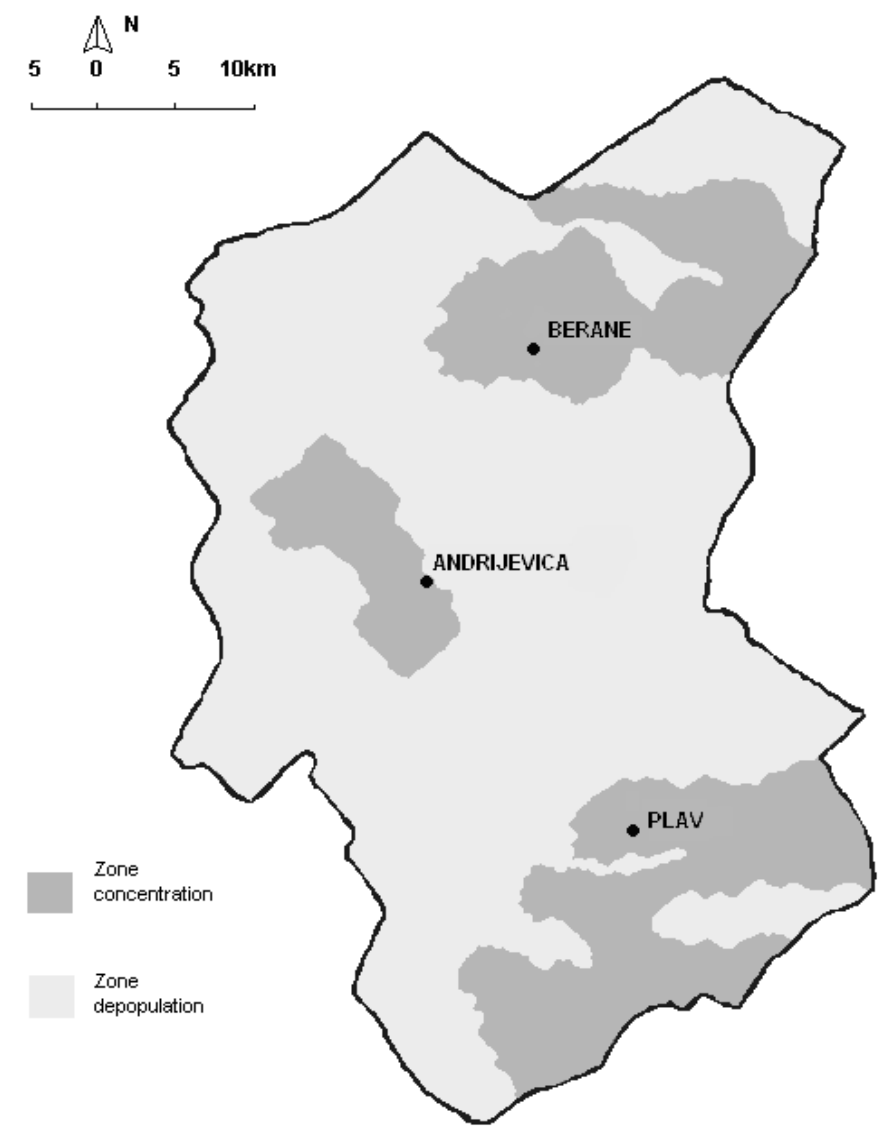

Figure 1. Zone of concentration and zone depopulation in northeastern Montenegro

The general conclusion is that the depopulation of the north-eastern Montenegro, after the 1971 settlement was higher in remote mountainous areas and municipal centers, while growth had community centers, which lie along important roads, especially the road, and one in the valley widening which the overall living conditions were more favorable (Bakic et al 1991). Thus, the hallmark of are modern development of rural areas in the region, given that the process of depopulation processes of industrialization and urbanization. . Age groups, due to migration and the reduction of fertility change and take on unfavorable characteristics, reduces the proportion of younger and older increases the proportion of the population. In 
both cases, the disturbed age structure has a reverse effect on the movement of the population (the size of reproductive contingent), but also to all other structures of the population (the size of contingent employment, population, compulsory school contingent, contingent dependent population ratio)( see more Rajović and Bulatović, 2012).

Table 2. Movement of the total population in northeastern Montenegro 1971-2003

\begin{tabular}{|c|c|c|c|c|c|c|}
\hline \multirow{2}{*}{ Space } & \multicolumn{2}{|c|}{ Total population } & \multirow{2}{*}{$\begin{array}{l}\text { Index } \\
71 / 03\end{array}$} & \multirow{2}{*}{ Area in $\mathrm{km}^{2}$} & \multirow{2}{*}{\multicolumn{2}{|c|}{$\begin{array}{c}\text { Density (the population } \mathrm{km}^{2} \text { ) } \\
1971.2003 .\end{array}$}} \\
\hline & 1971. & 2003. & & & & \\
\hline Zone concentration & 37.851 & 45.080 & 395,2 & 1.082 & 76,8 & 8,85 \\
\hline Zone depopulation & 31.042 & 9.578 & 68,9 & 404,1 & 35,0 & 111,6 \\
\hline Total & 68.893 & 54.658 & 126,0 & 1.486 & 46,4 & 36,8 \\
\hline
\end{tabular}

Source: Statistical Office of Montenegro, Census of Population (appropriate year), calculations by

General population density is one of the basic demographic characteristics that indicate the spatial distribution of population. In northeastern Montenegro, it was reduced from 46.4 $\mathrm{in} / \mathrm{km}^{2}$ (in 1971) to $36.8 \mathrm{in} / \mathrm{km}^{2}$ (in 2003). In areas of depopulation density is reduced from $35.0 \mathrm{in} / \mathrm{km}^{2}$ (in 1971) to $8.85 \mathrm{in} / \mathrm{km}^{2}$ (in 2003). In some rural areas of hill and mountain areas it is extremely low, for example: Cecuni $2.7 \mathrm{in} / \mathrm{km}^{2}$ (in $197110.0 \mathrm{in} / \mathrm{km}^{2}$ ), Kuti $3.3 \mathrm{in} / \mathrm{km}^{2}$ (in $19718,8 \mathrm{in} / \mathrm{km}^{2}$ ), Vuča $2.6 \mathrm{in} / \mathrm{km}^{2}$ (in $197115.4 \mathrm{in} / \mathrm{km}^{2}$ ). In contrast, in zones of concentration of population density increased from $76.8 \mathrm{in} / \mathrm{km}^{2}$ in 1971 to $111.6 \mathrm{in} / \mathrm{km}^{2}$ in 2003. Densely populated, urban areas in addition, characterized the settlement in the vicinity of urban centers and municipal Berane and Plav: Pešca $1497.5 \mathrm{in} / \mathrm{km}^{2}$; Gusinje 808.3 in $/ \mathrm{km}^{2}$; lower Luge $607.5 \mathrm{in} / \mathrm{km}^{2}$; Dolac 175, $8 \mathrm{in} / \mathrm{km}^{2}$; Budimlja $173.4 \mathrm{in} / \mathrm{km}^{2}$.

Formed from such a density, we can state the following:

1. First that the distribution of the population in northeastern Montenegro in 1971 was in correlation with the impact of geographic relationships of natural conditions (physical) type and

2. Second those rural settlements are still a source of power of the population (Bakić et al 1991).

Beginning of the eighties was the decisive moment. That in this period begin with the preservation of rural settlements, construction of traffic infrastructure, development of small businesses, today northeastern Montenegro, would not confirm the model selected as representative (typical), as in all categories figures as part of the dominant and widespread occurrence and trends in rural areas of Montenegro, which is treated and considered underdeveloped. With great certainty, it can be argued, that this distribution of the population in northeastern Montenegro had its causes in the economic underdevelopment, but also adverse effects on the natural growth and migration, which will show the following analysis.

Natural movement of population. The population in northeastern Montenegro depended on the balance of natural and migratory movements. The population issue, in addition to the rural exodus and the concentration of population in municipal areas, came to the fore the ongoing process of reducing population growth.

The birth rate in the municipalities of Berane, Andrijevica and Plav for decades has a tendency to decline. The birth rate of $22.2 \%$ in municipalities Berane and Andrijevica and $25.4 \%$ in the municipality of Plav, 1971 shows that for every 1,000 inhabitants in the municipalities of Berane and Andrijevica 22.2 babies born in the municipality of Plav 25.4 babies while in 2003, 11.1 children born in the municipality Andrijevica, 12.5 in Berane and 12.9 in the municipality of Plav (by the division of the People's Republic of Montenegro to the municipalities of 15.04.1960.godine Andrijevica municipality was abolished and then connected communication Ivangrad. From then until 1991, official statistics provide unique data for Ivangrad or municipality Berane, which applies to the municipality Andrijevica) (Rajović and Bulatović, 2013).

So in terms of territorial distribution of fertility in northeastern Montenegro, we can draw the following conclusions:

1. The birth rate would be more likely, that there is a higher standard of living, better conditions of employment, housing, education, childcare and 
2. That of Berane, Andrijevica and Plav no longer an inexhaustible source of labor force and population.

Despite falling birth rates, death rates show that for every 1,000 inhabitants in 1971 in the municipalities of Berane and died Andrijevica 6.2, 3.0 and the municipality of Plav population. So, there was an increase in the mortality rate. This is confirmed by data for 2003 and indicates that the mortality rate ranged from 3.21 deaths in Berane, 8.69 in the municipality of Plav Municipality and 15.7 Andrijevica. The biggest change in the relationship between fertility and mortality, and thus change the rate of natural increase had Andrijevica municipalities. These municipalities had negative population growth in $2003-4.6 \%$. In the municipality of Plav population growth that year was $4.21 \%$, and Berane $9.29 \%$. In the future we should expect a stagnation of population growth rate, due to the migration and adaptation of the current population in the region, a new way of life and plan members in the family)(see more Rajović and Bulatović, 2013).

The changes that have occurred in our society in the last decade of the last century, in between census 1971 and 2003.years, were affected by changes in population trends in the region. In addition to mechanical and natural movement of the population was under the influence of social change, namely the social crisis. If we take into account the determinants of fertility decline: decrease in the share of agricultural population $(9.1 \%$ of the total rural population), housing, health care, social protection, later marriage, and the changes that have occurred in this period, the apparent the social impact of the crisis on the level of the birth rate. Another consideration, and transition effects, the most important being the increase of unemployment, poverty, increased mortality rates, shorter life expectancy. The reduction in the already small number of live births are affected just unemployment, a very poor financial situation and social instability. On the other hand, the mortality rate has steadily increased due to inadequate health care, lack of medicines, poor diet, but also because of the increase in the proportion of the population over 60 years (Stojšin, 2004).

As a basic form of existence, the whole family during the emergence of development northeastern of Montenegro was a pillar of the organization of life and economic activities. Some reasons for its closure are deep, as the reasons for termination of life in many rural areas of our country. Probably the wrong attitude of society towards the family and relationships in it and caused the disturbed relations in other spheres of life and work. Not at this point, you can get into all of the importance of family in the development of population and economy of the region. "Modern science has neglected the role of family in shaping economic - demographic processes, which makes the totality of these processes can not explain, and some of them receive a stencil - an abstract form" (Boonefozc, 1968).

Population growth is the result of natural relations of movement and migration processes. If the region does not make any migration of the population, then the growth rate and population growth were the same, that there would be a territorial population balance. "However, this situation actually exists nowhere" (Ilić, 1973). There is not in the northeastern part of Montenegro. Therefore, the municipality Berane, Andrijevica and Plav has very complex demographic components related to population growth. In addition, to note that these components are territorially unevenly distributed causing the demographic imbalance, unstable economic conditions. These facts, as well as uneven economic development, compared to other regions of Montenegro, causing significant migration movements. These processes are 70's of last century were intense. "Therefore, their amounts in the general public are often taken as an important proof of the vitality of our socio-economic system. However, in our opinion, the right score can be obtained if the process is put in an objective framework or, if you locate the temporal, geographical and socio-economic "(llić, 1973). How long and to what extent the rate of population growth in the region should fall very hard to say because we do not have the necessary indicators of economic development in the future. But if the population growth rate is still declining, may be considered space in the time to get into a lot of difficult economic situation, due to demographic aging and reduce the working population.

Migration. From the aspect of nationality, it is possible to partition the migration: external (mobility across national borders) and internal (within the country). "The fact is that 
most developed migration in contemporary urban stage especially since the beginning of the seventies of the twentieth century to the present time" (Stamenković, 1996). By their nature were radical and immediately noticeable. Changing the image of the village in a short period of time, the effects are achieved with a different sign, occur primarily in rural areas and are born out of poverty. It is not very well known that it occurred where space is economically developed. With the rugged northeastern mountains of Montenegro, the whole are family down to the valley, moving closer to roads and easier life in urban areas. "This movement resembles a river that is constantly going down are mountain or the constant wind flow from higher to lower areas") (Pavlović and Radivojević \& Lazić, 2008). Whether you are coming or inhabited part of the Northeast Montenegro from local or distant parts, whether they are leaving the region in search of a better life, the residents had a strong influence on developments in the area. Arriving, they brought new customs, system of construction, aesthetics and culture of living. Leaving, we changed the image of the village, as removing the previous spatial relationships, and creating opportunities for someone new and not adapted to the environment adapts in space, which is happening quite often.

Their impact is evident in all areas of the territorial space of the complex considered in any relevant geographic features of the settlement (demographic, morph-physiognomic and functional). In this sense, is characterized by continuous changes in demographic characteristics (1948-53477, 1961-62993, 1971-68993, 1981- 69332, 1991-64954 and 2003 -54658 inhabitants), morph-physiognomic structure (modern functional zoning, types of houses...) and regional-functional characteristics (increase in functional capacity and development of new external functions - industrial, tourism....).

Group of important and characteristic features of population migration northeast of Montenegro in the last forty years, belonging to the following:

1. Changes in the territorial structure of the immigration population,

2. Matching period of industrial development with the continuing dominance of the migration phase of migration,

3. Significant representation of labor migration (temporary work) population abroad and

4. Developed and diversified regional daily movement of workers, pupils and students to other places in the same municipality, other municipalities in Montenegro, another of the Republic (Serbia) or a foreign country or to an unknown place of work or schooling.

Table 3. Indigenous and migrant population in municipalities with respect to the total population of the region in 2003

\begin{tabular}{|c|c|c|c|c|c|c|c|c|c|c|c|}
\hline \multirow[t]{2}{*}{ Space } & \multirow[t]{2}{*}{ Total } & \multicolumn{2}{|c|}{$\begin{array}{l}\text { Since the birth } \\
\text { of lives in the } \\
\text { same place }\end{array}$} & \multicolumn{2}{|c|}{$\begin{array}{c}\text { Total } \\
\text { immigrant }\end{array}$} & \multicolumn{2}{|c|}{$\begin{array}{l}\text { Settlers from } \\
\text { the territory of } \\
\text { a municipality }\end{array}$} & \multicolumn{2}{|c|}{$\begin{array}{l}\text { Displaced from } \\
\text { other } \\
\text { municipalities of } \\
\text { the same } \\
\text { Republic - } \\
\text { Autonomous } \\
\text { Province }\end{array}$} & \multicolumn{2}{|c|}{$\begin{array}{c}\text { Migrants from } \\
\text { other Republic } \\
\text { - Autonomous } \\
\text { Province }\end{array}$} \\
\hline & & Broj & $\%$ & Broj & $\%$ & Broj & $\%$ & Broj & $\%$ & Broj & $\%$ \\
\hline Andrijevica & 5.785 & 4.427 & 76,53 & 1.358 & 23,47 & 559 & 9,66 & 612 & 10,58 & 187 & 3,23 \\
\hline Berane & 35.068 & 28.088 & 80,10 & 6.980 & 19,9 & 3.559 & 10,15 & 2.062 & 5,88 & 1.359 & 3,88 \\
\hline Plav & 13.805 & 11.711 & 84,83 & 2.094 & 15,17 & 1.257 & 9,11 & 386 & 2,79 & 451 & 3,27 \\
\hline Region & 54.658 & 44.226 & 80,91 & 10.432 & 19,09 & 5.375 & 9,83 & 3.060 & 5,60 & 1.997 & 3,66 \\
\hline
\end{tabular}

Source: Statistical Office of Montenegro, Census of Population (appropriate year), calculations by.

The territorial structure of the studied population migration geo-space, suggests the following structural and developmental characteristics:

1. Major presence in the region has an indigenous population of $80.91 \%$ by municipalities Andrijevica $76.53 \%, 80.10 \%$ Berane and Plav $84.83 \%$ compared to the total population in 2003,

2. Total immigrant population in the region is $19.09 \%$, have a major presence, settlers from the territory of a municipality 5375 or $9.83 \%$, followed by settlers from the 
territories of other municipalities in Montenegro 3060 or $5.60 \%$, and finally, immigrants from Serbia and other state 1997 or $3.66 \%$.

3. Fluctuations in the level of participation of individual territorial categories are negligible, except for the categories of immigrant population from the same municipality and

4. Highlighted the apparent displacement of the population in the short geographic distance.

Per iodization of immigration in the northeastern part of Montenegro, is determined by the pace of socio-economic development, because the phase of the urban socio-economic development coincides with periods of immigration. Namely, in are period before 1940 and moved to the region 89 persons or $0.85 \%$ of the total number of immigrants (-26 Andrijevica or $1.91 \%$, Berane -53 or $0.76 \%$, Plav 10 , or $0,48 \%$ ), $1941-19601300$ persons or $12.47 \%$ (Andrijevica - 256 or $18.85 \%$, Berane -894 or $12.81 \%$, Plav -150 or $7.16 \%$ ). In the period $1961-1970$, the number of settlers in the region amounted to 1221 persons or $11.70 \%$ (Andrijevica - 166 or $12.22 \%$, Berane - 951 or $13.62 \%$, Plav -104 or $4.97 \%$ ).

Table 4. Per iodization and the volume of immigration

\begin{tabular}{|c|c|c|c|c|c|c|c|c|c|c|c|c|c|c|c|}
\hline \multirow{2}{*}{ Space } & \multirow{2}{*}{$\begin{array}{c}\text { Total } \\
\text { immigran } \\
\mathrm{t}\end{array}$} & \multicolumn{2}{|c|}{$\begin{array}{c}1940 \text { and } \\
\text { before }\end{array}$} & \multicolumn{2}{|c|}{ 1941-1960 } & \multicolumn{2}{|c|}{$1961-970$} & \multicolumn{2}{|c|}{$1971-1980$} & \multicolumn{2}{|c|}{$1981-1991$} & \multicolumn{2}{|c|}{ 1991-2003 } & \multicolumn{2}{|c|}{ Unknown } \\
\hline & & $\underset{r}{\text { Numbe }}$ & $\%$ & $\underset{r}{N u m b e}$ & $\%$ & $\underset{r}{N u m b e}$ & $\%$ & & $\%$ & & $\%$ & & $\%$ & & $\%$ \\
\hline . & & 26 & $\begin{array}{c}1,9 \\
1\end{array}$ & 256 & & 166 & & 167 & & 226 & & 378 & & & \\
\hline Berane & & 53 & $\begin{array}{c}0,7 \\
6\end{array}$ & 894 & & 951 & & 971 & $\begin{array}{c}13,9 \\
1\end{array}$ & 1.006 & $\begin{array}{c}14,4 \\
1\end{array}$ & 1.194 & $\begin{array}{c}17,1 \\
1\end{array}$ & & $\begin{array}{c}27,3 \\
8\end{array}$ \\
\hline & & 10 & $\begin{array}{c}0,4 \\
8\end{array}$ & 150 & 7,16 & 104 & 4,97 & 112 & 5,35 & 209 & 9,98 & 445 & $\begin{array}{c}21,2 \\
5\end{array}$ & & $\begin{array}{c}50,8 \\
1\end{array}$ \\
\hline & & 89 & $\begin{array}{c}0,8 \\
5\end{array}$ & 1.300 & $\begin{array}{c}12,4 \\
7\end{array}$ & 1.221 & $\begin{array}{c}11,7 \\
0\end{array}$ & 1.250 & $\begin{array}{c}11,9 \\
8\end{array}$ & 1.441 & $\begin{array}{c}13,8 \\
2\end{array}$ & 2.017 & $\begin{array}{c}19,3 \\
3\end{array}$ & 3.114 & $\begin{array}{c}29,8 \\
5\end{array}$ \\
\hline
\end{tabular}

Source: Statistical Office of Montenegro, Census of Population (appropriate year), calculations by

In the period 1971-1980, the number of settlers in the region amounted to 1250 persons or $11.98 \%$ (Andrijevica - 167 or $12.30 \%$, Berane - 971 or $13.91 \%$, Plav -112 or $5.35 \%)$. In the period 1981-1991, the number of settlers in the region amounted to 1441 persons or $13.82 \%$ (Andrijevica - 226 or $16.64 \%$, Berane - 1006 or $14.41 \%$, Plav -209 or $9.98 \%)$. The largest volume of immigration is related to the period 1991-2003 and then moved into the region 2017 persons or $19.33 \%$ (Andrijevica - 378 or $27.84 \%$, Berane - 1194 or $17.11 \%$, or $21-445$ Plav, $25 \%$ ). Therefore, the scope immigration related to the period of industrial development since the beginning of the $60 \mathrm{~s}$ of last century onwards that culminated in the early 90 of last century. Highlight the extent of the migration periods: 1981-1991. 1441 or $13.82 \%$, and $1991-2003$. - 2017 or $19.33 \%$.

The exact number of displaced inhabitants of Montenegro and their descendants around the world, certainly, we can not have definitive data. Various sources mention a figure of 90,000 to 120,000 Montenegrin emigrants. The fact is that there is no institution in Montenegro, which has accurate data on the number of Montenegrin emigrants abroad, and therefore not considered in the geo-space. However, all agree that this number is not small and it is increasing every year (Rajović, 2011). According to the census of 2003, 54816 citizens of Montenegro was temporarily working abroad, which was $8.84 \%$ compared to the total population of Montenegro. In relation to the total population of the municipality, the municipality of Plav temporarily working abroad was 57.4\%, 16.9\% Berane and Andrijevica $12.0 \%$ of the population (htpp://www.cg.dijaspora@cg.yu). In the meantime are ceased to operate the State Union of Serbia and Montenegro which means that the status has changed and people who are from Montenegro and live and work in Serbia. The exact number of people, it is difficult to give precise figures, but various estimates suggest that at least this number is between 60,000 and 80,000 . Reasons for not determine exact number of Montenegrin emigrants were numerous, and especially emphasize, illegal migration that have characterized the ex-Yugoslav space, as well as recording people with Montenegrin 
space in the receiving countries as Yugoslavs, Serbia and Montenegro citizens and exYugoslavs (htpp://www.cg.dijaspora@cg.yu). "There is no doubt that the departure of many, especially young people, is much more complex socio-geographical problem. State of the economy, level of industry and failure of agricultural development are decisive effect on the migration process. Job opportunities, job creation and the amount of personal income, are the causes that affect the process of movement of labor abroad. The desire to earn a short time to buy an apartment, made a house, bought the estate, car, tractor or other machinery, are common and expressed motivations of migration abroad"(Rodić, 1972). Spatial effects of our workers abroad are numerous and conspicuous in the region (spatial and functional changes in the organization of rural backyards, modern types of rural houses, commercial buildings).

The importance of the study of commuting between the village stems from the complexity of the relationship of commuting and migration of people to the outcome of the change of residence. Commuters are often potential migrants, and people with previous experience of migration, a daily migration for short distances most common method of adjusting the alternative migration (Holmes, 1971; Zax, 1994, Artis and Surinach \& Romani, 2000).

Daily migrants considered geo-space, which are the subject of our interest, can be divided into two categories: workers (2534 or $52.33 \%)$ and school youth - students $(2,318$ or $47.67 \%)$. The workers usually commute to the workplace in urban areas by the center of the municipality. The modernization of the economic structure, as a result of the transition from the dominance of production dominance of the service sector, in particular the development of information technology, leading to changes in the spatial distribution of commuting (Van der Laan, 1998). Of the total number of commuters (4852), workers who are employed or work in other places in the same municipality within the region is - $60.22 \%$, the second Montenegrin municipality of $-31.89 \%$, the Republic or another foreign country $-3,95 \%$ and an unfamiliar area of waste also $3.95 \%$ of workers. Quantitative indicators of the relations of people commuting by activity in a certain way about the organization are functional division in the economy and relations between different branches of activity" (Stamenković, 1989). Intense population growth of secondary sector of the economy $(27.80 \%)$ multi-influenced phenomenon of commuting, for accelerated development of the secondary sector follows the decline of the primary $(13.78 \%)$, on the one hand, while on the other, in parallel with the secondary sector, developed following the tertiary (19.82\%) and quaternary $(24.88 \%)$. This finding, among other things, vividly illustrated, the daily migration of the active population by occupation (see table no. 5).

Table 5. Commuting active population by occupation 2003

\begin{tabular}{|c|c|c|c|c|c|c|c|c|c|}
\hline \multirow{3}{*}{ Space } & \multicolumn{9}{|c|}{ Active who are employed work in } \\
\hline & \multirow[t]{2}{*}{ Total } & \multicolumn{2}{|c|}{$\begin{array}{l}\text { Other settlements } \\
\text { within the municipality }\end{array}$} & \multicolumn{2}{|c|}{$\begin{array}{l}\text { Another municipality } \\
\text { of Montenegro }\end{array}$} & \multicolumn{2}{|c|}{$\begin{array}{l}\text { Second Republic or } \\
\text { a foreign country }\end{array}$} & \multicolumn{2}{|c|}{$\begin{array}{c}\text { Unknown place of } \\
\text { work }\end{array}$} \\
\hline & & Number & $\%$ & Number & $\%$ & Number & $\%$ & Number & $\%$ \\
\hline Andrijevica & 669 & 349 & 52,17 & 292 & 43,65 & 13 & 1,94 & 15 & 2,24 \\
\hline Berane & 1.551 & 975 & 62,86 & 460 & 29,66 & 71 & 4,58 & 45 & 2,90 \\
\hline Plav & 314 & 202 & 64,33 & 56 & 17,83 & 16 & 5,10 & 40 & 12,74 \\
\hline Region & 2.534 & 1.526 & 60,22 & 808 & 31,89 & 100 & 3,95 & 100 & 3,95 \\
\hline
\end{tabular}

Source: Statistical Office of Montenegro, Census of Population (appropriate year), calculations by

Strengthening the spatial mobility of population in the northeastern part of Montenegro is following growth in the daily movement of students. Of the total number of commuting students $(2,318)$, students who study in other places in the same municipality within the region is $66.01 \%$, the second Montenegrin municipality of $17.33 \%$, other foreign country or the Republic $14.50 \%$ and an unfamiliar area of waste education $1.77 \%$ of their students. "Spatial distribution of daily mobility ..... school youth in municipalities ... inseparable from the natural and geographical features, geopolitical situation and the current level of socio- 
economic development, hence the important differences between them in terms of volume of commuting "(Stamenković, 1989) (see table no. 6).

Table 6. Commuting students in 2003

\begin{tabular}{|c|c|c|c|c|c|c|c|c|c|}
\hline \multirow{3}{*}{ Space } & \multicolumn{9}{|c|}{ Students are educated in } \\
\hline & \multirow[t]{2}{*}{ Total } & \multicolumn{2}{|c|}{$\begin{array}{l}\text { Other settlements } \\
\text { within the municipality }\end{array}$} & \multicolumn{2}{|c|}{$\begin{array}{l}\text { Another municipality } \\
\text { of Montenegro }\end{array}$} & \multicolumn{2}{|c|}{$\begin{array}{l}\text { Second Republic or a } \\
\text { foreign country }\end{array}$} & \multicolumn{2}{|c|}{$\begin{array}{l}\text { Unknown place } \\
\text { of work }\end{array}$} \\
\hline & & Number & $\%$ & Number & $\%$ & Number & $\%$ & Number & $\%$ \\
\hline Andrijevica & 458 & 288 & 59,38 & 162 & 33,40 & 29 & 5,98 & 6 & 1,24 \\
\hline Berane & 1.358 & 994 & 73,20 & 109 & 8,03 & 233 & 17,16 & 22 & 1,62 \\
\hline Plav & 475 & 248 & 52,21 & 140 & 29,47 & 74 & 15,58 & 13 & 2,74 \\
\hline Region & 2.318 & 1.530 & 66,01 & 411 & 17,33 & 336 & 14,50 & 41 & 1,77 \\
\hline
\end{tabular}

Source: Statistical Office of Montenegro, Census of Population (appropriate year), calculations by.

Until are advent of commuting between the different levels of the hierarchy within the network of settlements brought a number of factors. One is the desire to live on the second level of the hierarchy than the one in which the worker is employed (either in terms of the opportunities it offers a level of hierarchy or the presence of relatives, friends). In this case, the worker is willing to submit commuting costs, including the time needed (spent) on the daily journey. Another factor is the fact that an individual employed in a particular level of the hierarchy can not afford the cost of living at that level, but can not afford the cost of living in the second level, along with the cost of commuting. The third factor includes the possible benefits derived from the physical separation of work and residence (Parr, 1987).

Rue picture of the distribution of population in the region is difficult to assess. Among the external factors, not economic migration an important role in choosing the type of spatial mobility of the population and the migration flows have space organization. Imply a set of organizational factors that may influence or control to facilitate migration between the two spaces (Swindle and Ford, 1975). It is useful to ask why the border village of 500 inhabitants. This is the minimum number of inhabitants will assure the development of certain central functions, which will serve a wider area (Simonović and Ribar, 1993). Although the population of the rural villages is divide into two groups: (0 - 100 and $100-500$ people) for both can be said to belong to a group of rural settlements which are substantially flat. In this first, size of the group (18 settlements) has further depletion trend of space, a second group (63 villages), this trend is mitigated.

Today is very unevenly distributed network of settlements in northeastern Montenegro, make settlements with small populations. Most of them are from $100-500$ (63 settlements), followed by $500-1000$ (18 villages) and over 1000 (16 settlements). It is noticeable lack of settlements with over 2000 people (only 4 settlements with over 2000 inhabitants: 12651 Berane; Luge Beranske 2011; Gusinje 3015; Plav 5554). Only in these settlements, we can talk about the real potential for the development of central functions, and this size appears as other important Joints in numerical terms (the symbols used in Table $7 \bullet$ village belongs to the municipality Berane village belongs to the municipality of Plav $\boldsymbol{\nabla}$ village belongs to the municipality Andrijevica).

Table 7. Distribution of the population to population in urban areas

\begin{tabular}{|c|c|c|c|}
\hline & & & \\
\hline & & & \\
\hline
\end{tabular}




\begin{tabular}{|c|c|c|c|}
\hline Azanje & 146 & Velika & 417 \\
\hline Andželati $\mathbf{v}$ & 146 & Lubnice & 256 \\
\hline Babino & 446 & Luge Andrijevičke $\nabla$ & 165 \\
\hline Božići & 292 & Marsenić Rijeka V & 414 \\
\hline Bojovići $\nabla$ & 137 & Mašte & 210 \\
\hline Bor & 317 & Mezgalji & 208 \\
\hline Bubanje & 212 & Dolja \& & 315 \\
\hline Vrševo & 475 & Dosudes & 438 \\
\hline Glavica & 130 & Orahovo & 165 \\
\hline Gnjili Potok V & 118 & Pahulj & 141 \\
\hline Godočelje & 243 & Ponor & 146 \\
\hline Gornje Zaostro & 236 & Prisoja $\nabla$ & 387 \\
\hline Gračanica $\nabla$ & 336 & Radmuževići & 106 \\
\hline Dašča Rijeka & 195 & Rovca & 105 \\
\hline Dobro Dole & 272 & Savin Bor & 449 \\
\hline Trepča $\nabla$ & 267 & Seoca $\nabla$ & 125 \\
\hline Donje Zaostro & 149 & Sjenožeta $\nabla$ & 121 \\
\hline Dragosava & 173 & Slatina $\nabla$ & 419 \\
\hline Dulipolje & 135 & Đurička Rijeka @ & 438 \\
\hline Đulići $\nabla$ & 130 & Ulotina $\nabla$ & 284 \\
\hline Zagrađe & 296 & Crljevine & 118 \\
\hline Zagroje & 330 & Crni Vrh & 146 \\
\hline Zabrđe $\nabla$ & 342 & Stitari & 288 \\
\hline Javorova & 170 & Višnjevo \& & 190 \\
\hline Johovica & 258 & Gornja Rženica s & 269 \\
\hline Jošanica $\nabla$ & 166 & Grnčar \& & 360 \\
\hline Kaludra & 267 & Kolenovići \& & 484 \\
\hline Kalica & 250 & Mašnica \& & 314 \\
\hline Košutići V & 143 & Trepča $\nabla$ & 267 \\
\hline Kralje $\mathbf{7}$ & 268 & Skič o & 443 \\
\hline Kruščica & 109 & Kurikuće & 115 \\
\hline Crljevine & 118 & & \\
\hline \multicolumn{4}{|c|}{$500-1000$} \\
\hline Donja Vrbica & 831 & Radmanci & 646 \\
\hline Hotis & 585 & Trešnjevo & 600 \\
\hline Vinicka & 639 & Tucanje & 655 \\
\hline Meteh \& & 586 & Bogajićis & 599 \\
\hline Goražde & 599 & Kruševo s & 505 \\
\hline Gornja Vrbica & 833 & Murino s & 580 \\
\hline Dapsići & 779 & Petnjica & 778 \\
\hline Donja Ržen ica & 829 & Petnjik & 713 \\
\hline Lagatori & 969 & Lužac & 842 \\
\hline \multicolumn{4}{|c|}{$1000-2000$} \\
\hline Beran Selo & 1.568 & Trpezi & 1.416 \\
\hline Budimlja & 1.745 & Vusanjes & 1.887 \\
\hline Dolac & 1.335 & Vojno Selos & 1.036 \\
\hline Pešca & 1.857 & Prnjavor \& & 1.306 \\
\hline Andrijevica $\nabla$ & 1.193 & Buče & 1.048 \\
\hline Brezojevica \& & 1.035 & Martinovićis & 1.312 \\
\hline \multicolumn{4}{|c|}{ Preko 2000} \\
\hline Berane & 12.651 & Plav \& & 5.554 \\
\hline Luge Beranske & 2.011 & Gusinje \& & 3.015 \\
\hline
\end{tabular}

Source: Statistical Office of Montenegro, Census of Population (appropriate year), calculations by.

The existing network of settlements is a consequence of the no uniform density and concentration of population. A large number of settlements up to 500 people ( 81 settlements) are not suitable for modern developments vital for economic development. Namely, there is a lack of rural villages with rural center of over 1000 inhabitants (municipality Andrijevica) as a category that would connect the primary rural settlements of the municipality, with the center of the region - Berane.

Historical experience shows that the village still giving the city a vital workforce, the best people and the demographic they zoom in and refreshed. The villages are a long held tradition, positive character traits, maintains love for the preservation of national values (Bakić, 1988). Taking all this into account subjective factors of decision making and planning 
would have to bear in mind all these facts, and commitments to ensure their planning activities of the agents that will keep the life in the villages and preserve the demographic vitality, as prerequisites to secure national life on the cliff north-eastern region of Montenegro. Such a conception of the network of settlements would have created favorable socio-economic conditions for the spatially homogeneous development of all parts of the municipal territory, and that means a region as a whole.

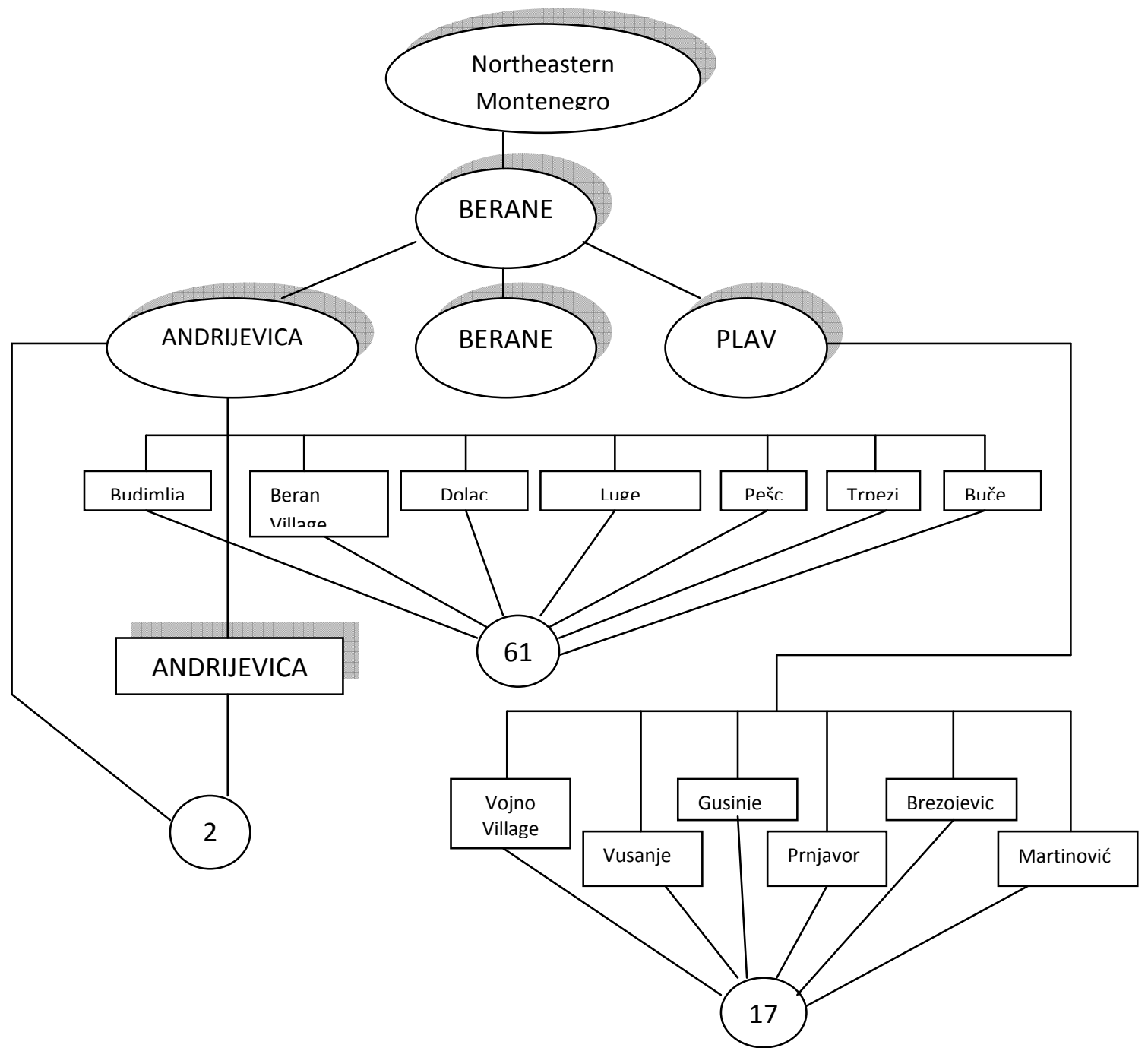

Figure 2. Functional system of settlements in northeastern Montenegro:

1. Berane as a regional center

2. Municipal centers

3. Community centers in rural villages with over 1000 population

4. Other rural settlements

- The numbers in circles indicate the village in a given territorial unit

The foregoing facts suggest the following conclusion:

1. Migrations are one of many factors in the evolution and transformation of the region,

2. Evident correspondence between migration flows and industrial development,

3. Contemporary migration flows in complex geographical regions have the highest representation of commuting workers, students, labor migration for temporary work abroad and

4. Notes the lack of rural settlements with the center, as a category that would connect the primary rural settlements of the region with the center - Berane.

In a variety of demographic changes caused by migration, as well as some relevant morph-physiognomic and functional changes, such as: 
1. Significant increase in urban population, and in connection with the representation of new urban facilities and

2. Regional-functional development, which is achieved through a gradual change of economic structure of urban settlements (Stamenković and Baćević, 1992).

The spatial development of urban settlements is to achieve the expansion in the peripheral, the construction of residential, commercial and recreational facilities. General urban plan is planning to functional zoning is constituted. Make it a center of urban areas, residential areas, recreational and work. This is accomplished using urban territory it is a functional need zone conditions of urban life.

Regional Development is functional mark major changes. They are reflected in the decline of primary and strengthening secondary, tertiary and quaternary functions of urban settlements. The main change is reflected in the fact that the leading agricultural functions ceded its place industry (transfer of agricultural to an industrial population). At the same time, due to increased mechanical influx of population, mostly from the surrounding rural areas, there is a transfer of rural to an urban population (Stamenković and Baćević, 1992). Some further analysis needs to show what is in today's economic conditions more acceptable and reasonable. Life according is to scattered small remote rural areas or urban settlement and development of industry in them. The urban areas of the region are still far from the actual extent of urban development.

The overall data presented in this northeastern part of Montenegro, can serve as a good framework to display the size of the chosen model in the context of global events. The studied region is one of the underdeveloped regions, where the dispersion due to the morphological structure of the picked-there were significant disparities in the relative size and growth trends in municipal centers (Berane, Andrijevica and Plav) and other settlements in the considered area. As the shattered village, structured by dense fragments (hamlet), remote and scattered on the territory of the corresponding region, the northeastern part of Montenegro is an interesting and distinctive way, fit into a systematic picture of the village of Montenegro. "Because it takes such a medium supplemented with new and more effective activities this achieving a more balanced economic development at the country level, which is one of the primary goals of local economic development. Positive examples of local and regional development, with well-defined strategy, were recorded in the following areas: Werttenberg Baden in Germany, Lorraine in France, Westphalia in the UK, Veneto and Friuli in Italy, Slovenia nearest us. This development concept is practical, since it includes all who want to cooperate; it does not cost much and gives results, which is of particular importance for underdeveloped countries "(Vojnović and Riznić \&Borić, 2009).

\section{CONCLUSION}

Results of analysis of population trends northeastern of Montenegro in the second half of the twentieth and early twenty-first century, suggests the following conclusions:

1. The population has increased in the period 1948-2003 to 53477 to 54658 population. Looking generally in relation to the 1948 population of the region increased by $2.16 \%$ in 2003, but with a tendency to decline from 1981.

2. On the basis of demonstrated tendencies in the movement of the total population in the region can be identified: depopulation zone and zones of concentration of population. The depopulation of areas which include 85 from a total of 113 villages, or $72.81 \%$ (1082 km2), the total area of the considered geographic space $(1.1486 \mathrm{~km} 2)$, census 1971 lived 37851 inhabitants (59.94\% of total population), and 2003, 9578 people (17.52\% of total population). Areas of concentration in growth of population, census 1971 they lived in 31042 people (45.06\% of total population), and 45080 inhabitants in 2003 (82.47\% of total population).

3. Parameters of natural increase are negative tendencies. The birth rate decreases, mortality increases. Thus, the birth rate is decreasing since the beginning of the seventies. So in 2003 the municipality Andrijevica was $-4.6 \%$, in the municipality of Plav $4.21 \%$, and Berane $9.29 \%$. 
4. Migration of population indicates an uneven population density and concentration of population. A large number of settlements up to 500 people (81 settlements) are not suitable for modern vital flow of economic development in the region. It is noticeable lack of settlements with over 2000 people (only 4 settlements with over 2000 inhabitants: 12651 Berane, Luge Beranske 2011, 3015 Gusinje, Plav 5554). Only in these settlements, we can talk about the real potential for the development of central functions, and this size appears as another important fact in numerical terms.

Finally, the demographic-economic problems of North-Eastern Montenegro should be viewed realistically, without undue optimism, pessimism and even less. The process of general and qualitative transformation of the region will be relatively very slow and time consuming. So you should work on it patiently, but persistently and continuously.

\section{REFERENCES}

[1] Bolčić S., Milić A.(2002), Serbia at the end of the millennium-destruction of society and changes in daily life, "Filip Višnjić", Belgrade.

[2] Tucović O., Stevanović, R (2007), Natural population of Belgrade in the second half of the twentieth and early twenty-first century, Geographical Institute "Jovan Cvijić", Serbian Academy of Sciences and Arts, Volume 57:144.

[3] Statistical Office of Montenegro (2011), Census (appropriate year).

[4] Holmes J.(1971), External Commuting as a Prelude to Suburbanization, Annals of the Association of American Geographers, Volume 61(4): 774-790.

[5] Swindell K., Ford,R. (1975), Places, Migrants and Organization: Some Observations on Population Mobility, Geografiska Annaler, Series B, Human Geography, Volume 57(1): 68-76.

[6] Parr J. B. (1987), Interaction in an Urban system: Aspects of Trade and Commuting", Economic Geogruphy, Volume 63( 3): 223-240.

[7] Zax J. (1994), When Is a Move Migration?, Regional Science and Urban Economics, Volume 24 (3):341-360.

[8] Van Der Laan L. (1998), Changing Urban Systems: An Empirical Analysis at Two Spatial Levels, Regional Studies, Volume 32 (3):235-248.

[9] Artis J., Romani, J., Surinach, J.(2000), Determinants of Individual Commuting in Catalonia, 1986-1991: Theory and Empirical Evidence, Urban Studies, Volume 37(8):1431-1450.

[10] Jaćimović B. (1989), Influence of depopulation of changes in agricultural structure Southern region, Institute of Geographical Science, Proceedings, Volume 36: 46.

[11] Spasovska M., llić, J. (1989), Problems of demographic development and the depopulation of rural areas in the SR Serbia, Geography Faculty of Science, Proceedings, Volume 36:69.

[12] Bakić R. et al (1991), Geography of Montenegro - population, "University for" Book.1, Nikšić.

[13] Rajović G., Bulatović, J.(2012), Some economic-geographic factors development of the example rural areas northeastern Montenegro, Russian Journal of Agricultural and Socio- Economic Sciences, Number 9( 9): 3-20.

[14] Rajović G., Bulatović, J. (2013), Analysis of shange in population structure: The Case Northeastern Montenegro, Journal of studies in social siences, Volume 2(1):1-30.

[15] Stojšin S. (2004), Society in transition and change population trends - example of Vojvodina, Sociological review, Volume 38(1-2): 355.

[16] Boonefozc E.(1968), Le monde est il surpleuple, "DII Press“, Nashate.

[17] Ilić J. (1973), Basic and dynamic characteristics of the regional growth of population in Serbia after World War II, Institute of Geographical Science, Proceedings, Volume 20:118-119.

[18] Stamenković Đ.S. (1996), Migration as a factor in the transformation of the settlement Svilajnac, Journal of Serbian Geographical Society, Volume 76: 14. 
[19] Pavlović M., Radivojević, N., Lazić, J. (2008), Analysis of movement and population structure of Vrnjačka Banja, Institute of Economics, Industry, Volume 1:111.

[20] Rajović G. (2011), Demographic characteristics of the modern labor migration from Montenegro to Denmark, Journal GeoScape, Volume (1-2): 2-10.

[21] Centre for expatriates in Montenegro (2009), Available www.cg.dijaspora@cg.yu

[22] Rodić P.D. (1972). Some socio - geographical problems of the contemporary migration of labor from abroad, Yugoslavia (1961 -1971), Institute of Geographical Science, Proceedings, Volume 19: 64.

[23] Stamenković Đ.S. (1989), Commuting (labor and school children) to central neighborhoods in Vranje area, Serbian Geographical Society, Book 68, Belgrade.

[24] Simonović Đ., Ribar, M.(1993), Regulation of rural territory and settlements," IVl”, Belgrade.

[25] Bakić R. (1988), Spatial planning-demographic and geographic aspects, "University for", Nikšić.

[26] Stamenković Đ., Baćević, M. (1992), Geography of the village, Faculty of Geography, Belgrade.

[27] Vojnović B., Riznić, D., Borić, S. (2009), The importance of defining the regional development strategy to build competitiveness, Institute of Economics, Industry, Volume 4: 61. 